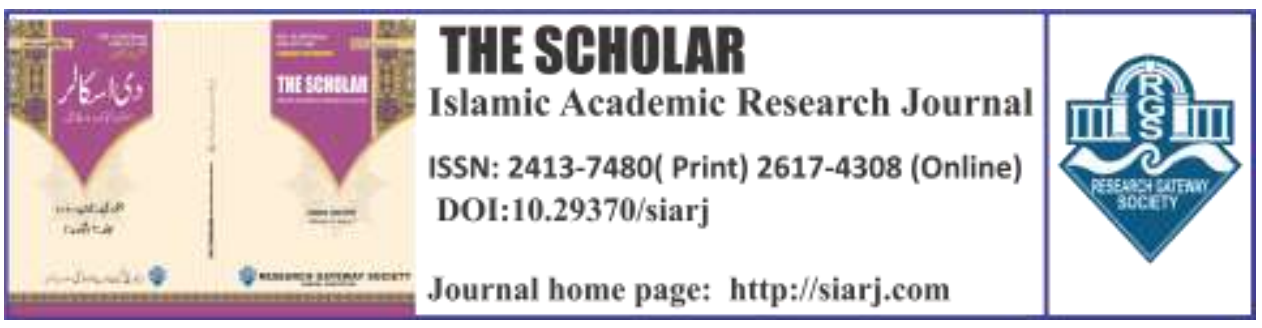

\title{
CHALLENGES CONFRONTED BY CONTEMPORARY MUSLIM WORLD AND THEIR SOLUTION IN THE LIGHT OF SEERAH
}

\section{Shahzada Imran Ayub}

Assistant Professor, Department of Islamic Studies, The University of Lahore, Lahore, Pakistan.

Email: drhfzimran@gmail.com

ORCIID IID:

https://orcid.org/0000-0002-5840-1646

\section{Saad Jaffar}

Lecturer of Islamic Studies, Department of Pakistan Studies Abbottabad University of Science \& Technology, Abbottabad, Pakistan. Email: Saadjaffar@aust.edu.pk ORCID IID: https://orcid.org/0000-0003-3438-9360

\section{Asia Mukhtar}

Ph. D scholar, Department of Islamic Studies, The University of Lahore, Lahore, Pakistan.

Email: gasia902@gmail.com

ORCID IID: https://orcid.org/0000-0003-3119-3442

To cite this article:

Ayub, Shahzada Imran, Saad Jaffar, and Asia Mukhtar. "ENGLISH-CHALLENGES CONFRONTED BY CONTEMPORARY MUSLIM WORLD AND THEIR SOLUTION IN THE LIGHT OF SEERAH." The Scholar-Islamic Academic Research Journal 6, no. 1 (May 31, 2020): 379-409.

To link to this article: https://doi.org/10.29370/siarj/issue10aren24

Journal

Publisher

DOI:

URL:

License:

Journal homepage

Published online:
The Scholar Islamic Academic Research Journal Vol. 6, No. 1 || January -June 2020 || P. 379-409 Research Gateway Society 10.29370/siarj/ issue10aren24 https://doi.org/10.29370/siari/ issue10aren24 Copyright c 2017 NC-SA 4.0 www.siarj.com 2020-05-31
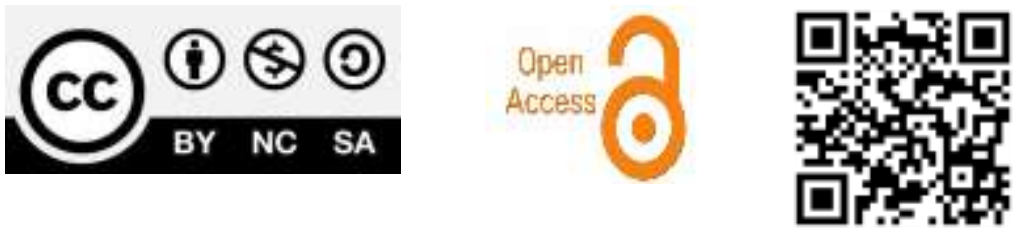
THE SCHOLAR (January- June 2020)

\title{
CHALLENGES CONFRONTED BY CONTEMPORARY MUSLIM WORLD AND THEIR SOLUTION IN THE LIGHT OF SEERAH
}

\author{
Shahzada Imran Ayub, Saad Jaffar, Asia Mukhtar
}

\begin{abstract}
:
In the modern times, the Islamic world is suffering from challenges rising internally and reaching from the external sources. The Seerah, being a complete code of conduct provides comprehensive way out to these challenges confronting individuals and whole Muslim Ummah. This research is conducted to provide solutions to all those challenges which the Muslim world is confronting these days solely in the light of the Seerah of the Prophet Muhammad PBUH. Every aspect of the life is covered by the Seerah and it is with this determination the solutions are offered from Seerah. The Holy Prophet (PBUH) himself took profound steps in order to deal with the internal and external challenges of the state of Madinah, and these steps are examples for the rest of the world. The steps he took include the Charter of Madinah, the peace treaty, letters to the kings, the conquest of Makkah and the farewell sermon. His teachings give insight regarding the challenges relating to an individual and a state. We get guidance regarding attitude, behavior, women rights, social, economic, political affairs of a state and it is extended to the defense system and foreign policy of the state. Hence, we can say that the prophetic insight, his foresight and understanding is exemplary not only for the Muslim world but also for the world of humanity. The system he provided can be implemented as a basic system at the state and international level.
\end{abstract}


KEYWORDS: Modern Times, Challenges, Internal, External Challenges, Humanity.

\section{INTRODUCTION:}

Islam is an organized and cohesive ideology with its own code of conduct, political, economic and social system. In modern times, Islamic State is suffering from global pressures, economic weakness, social backwardness and Internal and external instability. Differences and conflicts in the Muslim Ummah are created by making various conspiracies externally, criticizing Islamic civilization and culture and the peace of the Islamic State is ruined by accusing it of extremism and terrorism. There are issues like transgression of Islamic boundaries, liberal thinking, materialism, financial corruption, sectarianism and moral degradation. The life of the Holy Prophet (PBUH) is a perfect example to deal with these challenges individually and collectively, nationally and internationally. Upon his arrival in Madinah, he first established an organized society in the form of the state of Madinah, where the judiciary was supreme and the rule of law prevailed, life, property and honor was protected. The social, economic, legal, family and moral rights of the people were determined. Peace and order, brotherhood, equality, justice, patience, and tolerance are such values which were introduced by Holy Prophet. He made the protection of the lives and property, honor and religious rights of the minorities a part of the constitution. Abolished the system of economic exploitation and introduced a system of economy which strengthened the economic situation individually and collectively. In order to deal with the internal and external challenges of the state of Madinah, the Holy Prophet (saw) took steps such as: Mowakhat Madinah, the Charter of Madinah, Hudabiyya agreement, Letters to the Kings, Conquest of Makkah and Farewell Sermon. The defense and foreign policy of the state of Madinah 
is a manifestation of your prophetic insight, foresight and understanding, which has a wide range of guidance not only for the people of Islam but for the whole humanity. There is a need that Muslim states implement the model of teachings of the Holy Prophet (PBUH) as a basic system at the state and international level. In today's age, time has come a long way in terms of its social, societal, civil, scientific and technological conditions, despite this, the Muslim state suffers from various problems. The problems and challenges we face today are mainly due to our internal disunity and lack of unity and solidarity among the Muslim Ummah. Distance from the religious and cultural values of Islam, deviation from the teachings of the Prophet (peace and blessings of Allah be upon him), self-forgetfulness and forgetfulness of God.

Molana Abu-ul-Kalam writes under the heading of the natural principles of rise and fall:

"Take any nation and place any piece of land in front of you, investigate the situation since its recorded history, you will see that the reality of its entire history is nothing but a continuous story of inheritance, that is, one nation was conquered, then it was wiped out and the other became the heir. Then they also had to be erased and space became vacant for the third heir. The Qur'an says that there is nothing but heir and inheritance. Now we have to think about why those who are forced to leave inheritance, and why those who inherit are entitled to inherit"

\section{CRITICISM OF ISLAMIC CIVILIZATION AND CULTURE:}

One of the challenges faced by Islamic states is the attack of Western civilization on Islamic civilization and culture. By shaking the Muslim

$1 \bar{A} z \bar{a} d$, Abū al Kalām, Quran ka Qānūn e 'Urūj o Zawāl, (Lahore: Maktaba Jamal, 2004), p: 100 
Ummah intellectually, their perfect civilization and culture, social, moral and ethical values are being trampled. As a result, the grip of Sharia was weakened and Islam departed from our lives in such a way that we remained Muslims in name only and this is how Allama Iqbal pointed out our Islamic identity.Western thinkers when talk about Islam, they criticize Islam. Their assessment, while showing the superiority of their civilization, seems to touch the limits of contempt of Islam.

\section{EXPLAINING THE CULTURAL ROLE OF ISLAM, F.}

\section{FUKUYAMA WRITES:}

"Islam is a systematic and coherent ideology with its own code of conduct and system of political and social justice (Initially) the popularity of Islam was universal which reached the common man. (In modern times) Islam undoubtedly defeated liberal democracy in many parts of the Muslim world and it proved to be a threat to liberalism even in countries where it did not gain direct political power. However, despite the use of force by Islam in the current revivalist struggle, the reality is that the religion has no appeal outside the countries where Islam originated culturally. It seems that the era of cultural conquests of Islam has passed. It can win the hearts of those who are suffering from some misunderstandings but it does not resonate with the youth of Berlin, Tokyo and Moscow. One Billion means, One-Fifth of the World's Population although are culturally Islamic, still Muslims Cannot Challenge Liberal Democracy in their territories. Undoubtedly, with the passage of time, the 
Islamic world, instead of defeating liberal ideas, is becoming weaker and weaker before them."2

All of this propaganda can only be effectively countered if we present Islam as a perfect civilization, that Islam gives an ideal culture in which values and deeds, economy and morals are interconnected.

Dr. Burhan Ahmad Farooqi writes:

"Western nations want to convince developing nations that no follower can go beyond its leader, so one way to assert one's supremacy and to persuade one's followers is to divert them from their intellectual base and cultural pattern. Along with that, entangle them in such a tug of war, thanks to which they can give up the belief in the effectiveness of their system, and follow in their footsteps and never emerge as a rival. The challenge posed by modern times to all mankind, if we find the answer without following the footsteps of Western civilization, will not allow us to develop on the basis of our intellectual base and our cultural model”3

The Holy Prophet (PBUH) gave a new civilizational breath to the civilization of this world. The world's worn-out leash system has been changed radically. He established discipline and laid the constitutional foundation of life. Established a brotherhood among human beings which developed the attributes of love and affection, brotherhood, cooperation, unity and harmony between the individual and the community, and established the system of state on the system of shura.

2 Simon Murden, Sulture in World Affairs in John Baylis \& Steve Smith's The Globalization of World Politics, (OUP, 2001), p. 461

3 Fārūqū, Dr. Burhan Ahmad, Qur'ān or Musalmāno $k$ Zindah Masā'il, ('Ilm o 'Irfān Publishers, 1999), p: 86 


\section{Challenges confronted by contemporary Muslim world and their}

solution in the light of Seerah

He put an end to oppression and provocation in religion. Nobody can be hated for being a disbeliever, but the People of the Book are also allowed to have marital relations with women. Hence, Islam has forbearance and tolerance and it wants to build a world that is free from oppression, hatred, envy, jealousy and narrow mindedness and is the cradle of peace, security and love for mankind. The Holy Prophet (PBUH) through his teachings and practical steps gave the method and direction of the development of Islamic civilization, which led to the emergence of a civilization, in the coming times, which is glorious and powerful in all other respects in other civilizations and is contained in itself.

This is what a Western thinker admits in his writings:

"Besides their military merits, their strength included extraordinary artistic sensitivity in literature, architecture and symbolic imagery : a commitment to justice for all, no matter how weak, a tolerance for non-believers that was unusual for its time .... In economic and administrative affairs, the Ottomans had a far more efficient tax system and better control of their provincial authorities than any European government of the fourteenth through sixteenth centuries ${ }^{4 "}$

Apart from his military prowess, his power lies in the extraordinary artistic sentiments in literature, architecture and symbolic imagery, the establishment of justice for all, no matter how weak, for the tolerance and tolerance of non-Muslims in this age were equal to none, The Ottomans had a very successful tax system in economic and administrative matters

4 Philip J. Adler, Randall L. Pouwels, World Civilizations, p. 495 


\section{Challenges confronted by contemporary Muslim world and their solution in the light of Seerah}

and they had better control over their provinces than the European governments of the fourteenth to sixteenth centuries.

\section{LACK OF MODERN SCIENCE AND TECHNOLOGY:}

The biggest reason for the decline of Muslims is the distance from modern and Islamic sciences. The journey from this decline to the rise is not possible without scientific progress. It is only knowledge through which they can compete with other nations in every field and with this, they can move ahead in the race of political, economic and social development. It is important for Muslim states to equip their people with the latest scientific and technological knowledge so that they can compete with the developed countries by utilizing the natural resources. Not all Muslim countries are paying attention to scientific and industrial development as a whole. In order to dispel the doubts and suspicions of the youth in modern times, it is necessary to give a scientific interpretation of Islamic teachings so that they may be satisfied with scientific arguments, and the young generation may be acquainted with the deeds of Muslim scientists. And let it be known to them that this is your lost heritage which your fathers had once and now others are taking advantage of it and we have left it behind us. For a long time no famous scientist has been born in any Muslim state and no new invention has been invented, that is why we are dependent even for smallest things.

This fact is acknowledged by Western thinkers themselves. Joseph Schacht writes:

"There is no doubt that the Islamic sciences exerted a great influence on the rise of European science; and in this renaissance of knowledge in the west there was no single influence, but diverse ones; the main influence 


\section{Challenges confronted by contemporary Muslim world and their}

solution in the light of Seerah

was of course, from Spain, then from Italy and Palestine through the crusaders, who had mixed with Muslims and seen the effect of sciences in Muslim culture ${ }^{5 "}$

As far as religion is concerned, it has made us aware of the fact that all the universe scattered in the heavens and the earth has been subjugated to man. It is now man's job to use everything in the universe to the best of his abilities.

The Holy Prophet took such steps for the promotion of scientific knowledge and patronage of science and art in such a way that a nation proud of its ignorance soon became the lead in science and art of the whole world.

The first revelation of the Quran took the message of science:

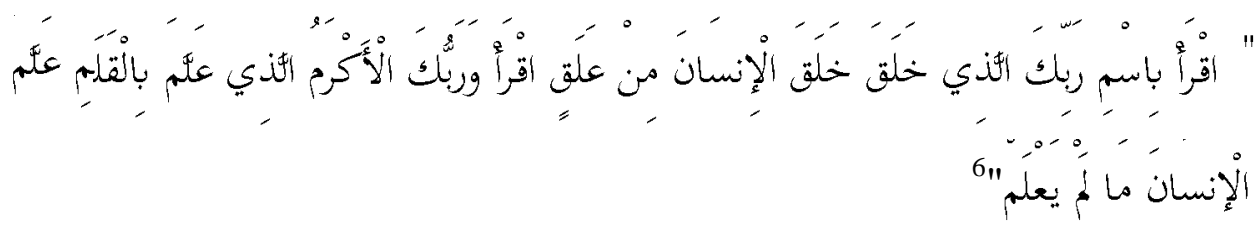

Read, O Prophet, in the Name of your Lord created humans from a clinging clot. Read! And your Lord is the Most Generous. Who taught by the pen . taught humanity what they knew not.

Dr. Tahir-ul-Qadri has interpreted this verse as follows:

"The first verse of the first revelation, which was revealed to the Crown Prince of Mercy, provided the scientific basis of Islamic theology and ethics. The second verse explained the scientific basis of biology and genetics. The third verse invites human beings towards Islamic ideology and philosophy of life. The fourth verse sheds light on the philosophy of 


\section{Challenges confronted by contemporary Muslim world and their solution in the light of Seerah}

knowledge and education and the means of knowledge and the fifth verse opens the door to research in all fields of knowledge and cognition, thought and art and philosophy and science",7

At the time of the revelation of the Holy Prophet (PBUH), Christianity was teaching monasticism and Platonism was teaching luxury. If these two trends continued to flourish in the same way, science and knowledge would end. But Islam reversed these trends and laid the foundations of current experimental science, emphasizing the acquisition of knowledge and the use of human powers of observation. It invited to study the landscapes of nature and encouraged the children of Adam to seek the signs of the Almighty in the outside world.

Almighty Allah says:

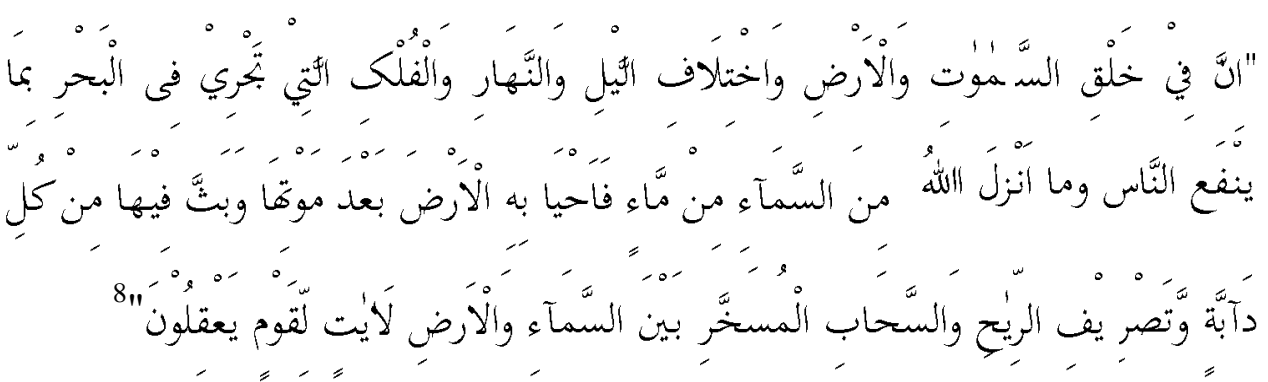

Surely in the creation of the heavens and the earth, and in the rotation of the night and the day, and in the ships which carry in the sea the things which benefit men, and in the water which it sends down from the sky. Then He revives therewith the earth after its death, (the earth) in which $\mathrm{He}$ has spread all kinds of animals, and in the changing directions of the winds

7 Dr. Tahirul Qādrī, Islām or Jadīd Science, (Minhāj al Qur'ān Publications, 2001), p: 77

8 Al- Qūrān:2,164 


\section{Challenges confronted by contemporary Muslim world and their solution in the light of Seerah}

and in the cloud which is between the heavens and the earth, there are (many) signs for the people of understanding.

The Prophet (peace and blessings of Allaah be upon him) emphasized on the acquisition of all kinds of knowledge including sciences and arts, and said:

$$
\text { "الحكمة ضالة المؤمن فحيث وجدها فهو أحق بها"9 }
$$

Wisdom (ie knowledge) is the lost heritage of the believer wherever he finds it he is more entitled to it than others.

These facts prove how the teachings of the Holy Prophet (PBUH) have left a deep impression on modern science and revolutions.

\section{ECONOMIC PRESSURES:}

Muslim states today face many economic challenges as a whole they are economically weak. Muslim states are facing the problems of having low per capita income, widespread poverty, poor resource allocation, high illiteracy, poorly trained workforce, widespread unemployment, corruption, misuse of resources, dependence on foreign loans and foreign aid. The economic policy of a state is important for the economic development of any state. Islamic states lack economic equality, their subjects are deprived of basic necessities of life. They look to the western world for education, health, housing and employment and the Muslim rulers are indulging in their luxuries. Economic inequality is increasing day by day. The rich get richer and the poor get poorer, which causes a lot of social problems. Efforts are being made internationally to

\footnotetext{
${ }^{9}$ Al Tirmidhī, Al Sunan, Ḥadīth \# 2687
} 
Address these issues, their purpose is stated by Dr. Burhan Ahmad Farooqi as follows:

"The slogan of all international economic plans is philanthropy but in reality they are intended to exploit economically weaker nations and countries for their own benefit by exploiting them"10

Islam has provided a complete system for the elimination of economic chaos in the society. The Holy Prophet migrated from Mecca with his Companions to Madinah and founded the state of Madinah. After that, the biggest problem faced by the Muslims was the economic problem. After the establishment of the Islamic state of Madinah, this is the first step Prophet Muhammd PBUH took in the process of implementation of what is known in history as "Moakhat Madinah"11

This is how the Qur'an condemns concentration of wealth:

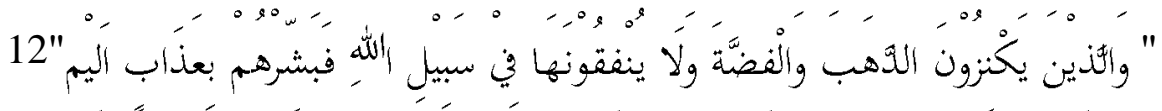
"And as for those who hoard up gold and silver and do not spend it in the way of Allah, announce to them a painful chastisement".

The Holy Prophet (sws) has commanded to distribute surplus wealth to the needy. It is narrated on the authority of Hazrat Abu Saeed Al-Khudri:

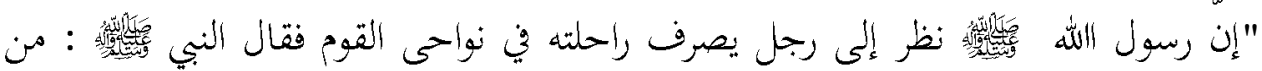
كان عنده فضل ظهر فليعد به على من لا ظهر له ومن كان له فضل زاد فليعد به على

\footnotetext{
${ }^{10}$ Fārūqī, Dr. Burhan Aḥmad, Qur’ān or Musalmāno k Zindah Masā‘il, p: 89

${ }^{11}$ Ibn Hishām, Al Sīrah al Nabaviyyah,Vol 3, P:36

${ }^{12}$ Al- Qūrān:9,34
} 
The Holy Prophet (peace and blessings of Allah be upon him) saw a man turning his horse towards a population, so the Holy Prophet (peace and blessings of Allaah be upon him) said: Whoever has an extra conveyance should give it to a person who does not have a conveyance and whoever has a stock of food should give it to a person who does not have food until we begin to think that None of us has any control over surplus wealth.

In the Islamic State, Zakat and Ushr, Khums, Sadaqat, Kafarah, Inheritance and Wills are important sources of mutual wealth and mutual aid through which wealth circulates. The Holy Prophet (SWS) ordered to give the right to livelihood to all members of the society on equal basis. Hazrat Abu Saeed Al-Khudri (may Allah be pleased with him) narrates:

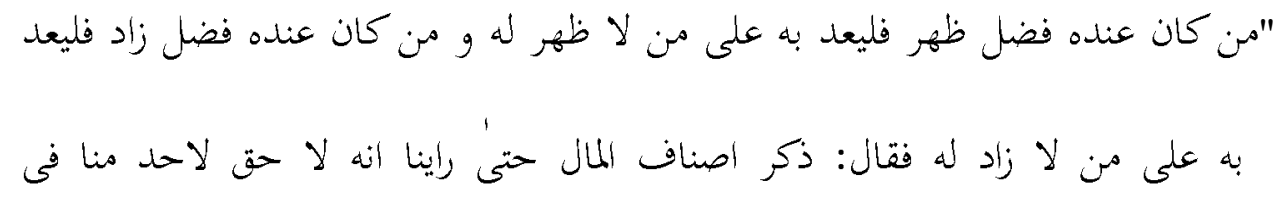

The one who has more than the required conveyance should return it to the one who does not have the required conveyance. He who has more food and goods than he needs, should give them to him who does not have the food he needs. We even thought we had no right to anything superfluous.

Nowadays, our rulers spend a lot of money on their luxuries in the name of various allowances from the state. In order to put an end to this

\footnotetext{
${ }^{13}$ Ahmad bin Hambal, Al Musnad, Hadīth \# 11311

${ }^{14}$ Șaḥị̣ Muslim, Hadīth \# 1728
} 
thinking, Hazrat Omar Farooq (RA) strictly forbade all government officials from economic extravagance in his time.

It is narrated by Imam Bukhari:

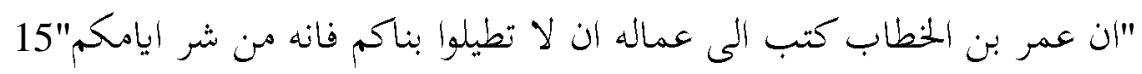

"Hazrat Umar Farooq (RA) issued a written instruction to the privileged and officers of his caliphate not to build their residences high, as such an act is a sign of the worst period".

\section{Allegations of terrorism:}

Today, terrorism is raining down on all Muslim countries, Afghanistan, Iraq and Palestine. Why is this whole game of bloodshed and oppression and barbarism special to the Muslim nation? Instead of reaching the bottom of the incidents of terrorism that are taking place or which are being carried out for a purpose, the heads of innocent Muslims and Muslim organizations are being imposed? Why are Muslim youths being picked up at any time on false accusations of artificial events? Why are they being tortured behind bars on all sorts of horrific charges and lawsuits? Why are Muslims being treated with brutality and cruelty and this barbaric attitude?

In the Western world, the media only highlights the actions and incidents of extremism and terrorism in relation to the Islamic world and does not explicitly highlight the positive aspects of Islam, true peaceful teachings and humanitarian philosophy and practices. It does not even mention the hatred, condemnation and opposition against terrorism in the Islamic world itself. As a result, Islam and extremism and terrorism have

\footnotetext{
${ }^{15}$ Șaḥị̣ Al Bukhārī, Hadīith \# 452
} 
been negatively bracketed, and the situation is that as soon as the name of Islam is heard, the image of terrorism begins to emerge in the minds of the West. Not only is the Muslim youth growing up in the West extremely disturbed, hesitant and anxious, but the youth of the Islamic world as a whole are suffering from ideological, intellectual and practical turmoil and mental confusion.

Such tensions continue to escalate tensions between the Islamic world and the West, and the rise of terrorism is paving the way for further intervention and pressure on Muslim states. Then this gulf is not only pushing humanity towards interfaith animosity globally but also the prospects of peace and mutual tolerance in the global human community are disappearing.

Terrorism and violence contradict Islam's policy of peace, but some mischievous vested interests and Western powers want to give the impression that Islamic teachings are responsible for the current unrest and violence.

The fact is that the label of terrorism, Islam and the game of sticking with Muslims is part of a global conspiracy. In order to fulfill this duty, the anti-Muslim organizations of the Islamic countries and other countries are trying their best to unite it with Islam and Muslims and call Islam a "terrorist religion" and Muslims a "terrorist nation", they want to prove it.

"The national, regional and international causes of terrorism are fundamental to global issues such as injustice to Muslims in some cases, double standards of superpowers in some regions and long term aggression to eradicate extremism in many countries. In that case, we have to make the international community realize that, the West must end its double standards; the fire of terrorism can be quenched by eliminating 
inappropriate treatment of Muslims in Palestine, Kashmir, Afghanistan, Iraq, Chechnya and other developing Islamic countries. At the national and international levels, there must be an end to all such motives that confuse the people and strengthen the secret forces behind terrorism"16

However, Islam is a religion of love. It conveys the message of peace and brotherhood to all nations and societies and inculcates mutual brotherhood, love, respect and mutual justice for all mankind. Islam itself is a religion of peace and tranquility and urges others to live in peace and tranquility. This is the greatest proof that Islam is a religion of peace and security that the ALL Almighty has chosen the name 'Islam' for the religion He has sent.

Allah ALL Mighty says that:

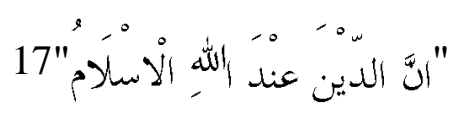

"Of course, Islam is the only religion."

A man asked the Holy Prophet (peace and blessings of Allah be upon him): O Messenger of Allah! Which Islam is the best? It is said by Hazrat Muhammad peace be upon him.

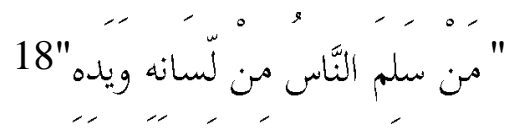

"(Islam is the best of the person) from whose tongue and hand all people are safe".

\footnotetext{
${ }^{16}$ Dr. Tahirul Qādrī, Qarārdād e Aman, (Minhāj al Qur'ān Publications, 2016), p: 79

${ }^{17}$ Al- Qūrān:3,19

${ }^{18}$ Aḥmad bin Ḥambal, Al Musnad, Ḥadīth \# 6753
} 
Hazrat Abu Hurarah (may Allah be pleased with him) narrated that the Holy Prophet (peace and blessings of Allah be upon him) praised the believer and said:

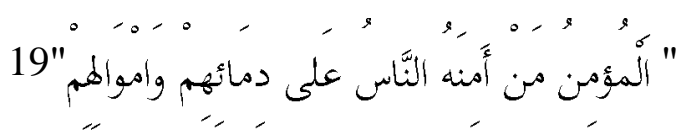

"A believer is one with whom people consider their blood (i.e life) and wealth safe".

\section{CULMINATION OF UNITY:}

It is an indisputable fact that in the rise and fall of nations, prosperity, unity and harmony, mutual brotherhood and sympathy and mutual dissension and disunity, separatism, and mutual hatred and enmity have a great role to play. The humiliation and disgrace that Muslims are facing in modern times cannot be compared with any earlier era and we have never observed such weakness in Muslims as we see in today's Muslim. That is why Muslims have no international significance today. Why is the Muslim Ummah suffering from this problem?

There may be many reasons for this, but the most important and the real one is discord, anarchy and separatism. This is the disease that has paralyzed the Muslims today and due to which the ungodly are dominating the Muslim states today. One of the great tragedies of the Islamic Ummah today is that they are divided despite having one God, one Messenger and one Qur'an. We have left behind the legacy of unity and mutual solidarity that we inherited from our forefathers, and on the contrary, today other nations seem to be united and striving to achieve their legitimate and illegitimate goals.

\footnotetext{
${ }^{19}$ Al Nasā‘̄ị, Al Sunan, Hadīth \# 4995
} 


\section{PREJUDICES ARE COMMON:}

The root of our problems today is the fact that our society is mired in racism, regional, linguistic and sectarian prejudices and have become against each other. We have lost an arm because of regional and linguistic divisions and enemy's plots fabrications. Despite this, our political and religious leadership is dividing the nation into different sections for its nefarious purposes.

Muslims have been repeatedly instructed in the Qur'an to end their differences and become united:

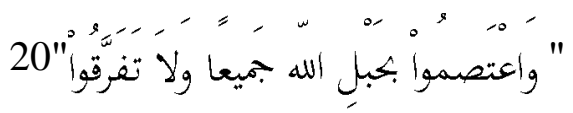

"And hold fast to the rope of Allah together, and do not be divided"

According to the interpreters, "Hablullah" means the Book of Allah and the Sunnah of the Prophet. Therefore, the the followers of Muhammad SAWW has two strong foundations of unity and harmony in the form of the Book of Allah and the Sunnah of the Prophet. The Messenger of Allah, may Allah bless him and grant him peace, said:

$$
\text { "تركت فيكم امرين لن تضلوا ما تمسكتم كما كتاب الله و سنه رسوله"21 }
$$

"I am leaving two things between you, as long as you hold fast to these two things you will never go astray and that is the Book of Allah and the Sunnah of the Messenger"

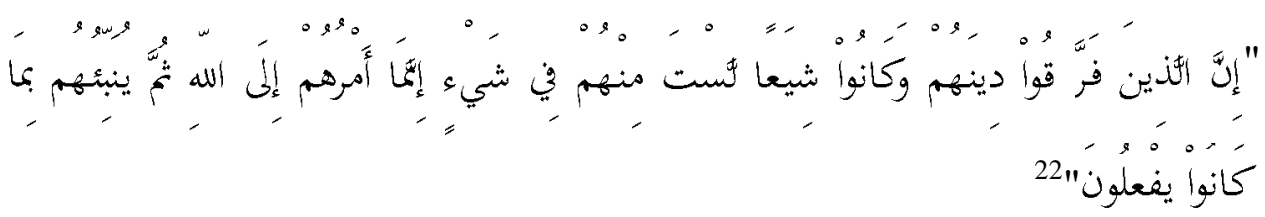

\footnotetext{
${ }^{20}$ Al- Qūrān:3,103

${ }^{21}$ Mālik bin Anas, Al Mu'watțā, Hadīth \# 1395
} 
Surely (as for) those who split their religion into different sects, you do not belong to them in anything, it is only among their affair and it is returned to Allah. He will then inform them of what they used to do.

Allah Almighty declaring mutual discord and dissension and pride and arrogance the way of polytheists said:

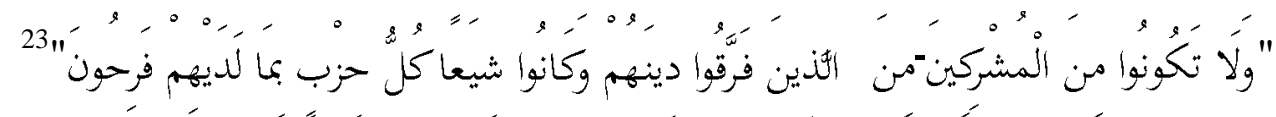

"And do not be of the polytheists. Not one of those (Jews and Christians) who have torn their religion into pieces and those who have torn their religion into pieces and they have become sects, each group descends to what it has"

When people are divided into different groups, by not keeping unity and harmony in place, what would be their fate and how do they get their end result? Explaining this, Allah said:

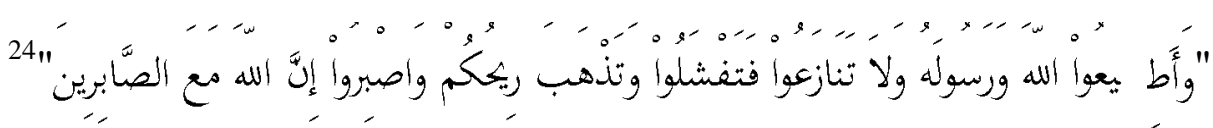

"And obey Allah and His Messenger (peace be upon him) and do not quarrel with one another, lest you become cowards, and your wind (i.e., strength) will go weaker in front of your enemies. Be patient, for Allah is

with those who are patient". "The Prophet (peace and blessings of Allah be upon him) has issued several edicts to maintain unity and harmony among the believers. The Prophet (peace and blessings of Allaah be upon him) did not like

\footnotetext{
${ }^{22}$ Al- Qūrān:6,159

${ }^{23}$ Al- Qūrān:30,31

${ }^{24}$ Al- Qūrān:8,46
} 
differences in his ummah, so he used to warn them of differences by giving examples of previous ummahs" 25

The critical situation of Muslims around the world today demands that all Muslims, especially the heirs of the Prophets, call for unity and solidarity, as well as describing its virtues, to make some practical programs and strategies for it. These differences have been created by some of our elders of the nation, our religious scholars and so-called nation-selling leaders by stirring up differences of opinion and creed.

Generally, the idea of unity of the nation is presented in such a way that everyone has complete freedom to practice his or her sect and basically the survival and protection of all sects as well as Muslims can come together on one platform. The sectarian divisions must first be eliminated and the Muslim Ummah must first create unity in its beliefs and ideologies by making the Qur'an and Sunnah its ideal and beacon, first, let the Muslim Ummah unite in its beliefs and ideologies. When the beliefs and ideologies become correct, then naturally there must be unity among the Muslims.

It is noteworthy that the Muslim Ummah is a victim of extremism and terrorism in the face of prejudices, sectarian tensions and conflicts. There is a need to strongly discourage sectarian prejudices, linguistic and regional arrogance and takfiri slogans from Muslim societies. All the elements that spread sectarianism should be suppressed so that an atmosphere of unity and solidarity can be established in the society.

Muslim states need to reconsider their foreign policies for mutual unity and harmony. Muslims do not have good relations with each other, let

\footnotetext{
${ }^{25}$ Al Bukhārī, Șaḥịh Al Bukhārī, (Dār Ṭawq al Najāh, 1422), 4: 175
} 
alone with other countries. For this, the foreign policy of the Holy Prophet (PBUH) is a beacon for us. He laid the foundation of the first Islamic state in Medina and kept an eye on Da'wah Islam as well as foreign strategy. Today, there is a need for the Ummah to become a Muslim Ummah as envisioned by the Qur'an and Hadith.

\section{Unstable political system:}

Today, the entire Muslim Ummah is under political pressure from the West. The West wants to conquer every Muslim state politically. If we look at the past history of Islam, the destruction of Baghdad is a political attack; the destruction of Muslims in Spain is also a political event. Similar pressures are faced by today's Muslim states. Establishing political harmony is an important requirement of the time for national welfare, national unity and solidarity and for the stability and integrity of the country. The Islamic world lacks credible and far-sighted leadership at the moment and most of the Islamic countries have not been able to come up with a single platform due to which the ship of the Muslim Ummah is in turmoil today. The Islamic world needs effective, credible and serious leadership to present its issues to the international community. Because the incompetence of the political leadership and the politics of confrontation where it is an obstacle in the way of national development, it is also a threat to the integrity of the country. The biography of the Holy Prophet (PBUH) is a beacon for us to end this political turmoil.

\section{Reforming system of governance:}

The state of Madinah was an ideological state and the foundation of this state was laid immediately after the migration to Madinah. This was the beginning of the journey of mercy towards the completion of the Mustafavi Revolution. The Islamic Movement was entering the phase of revolution. The Holy Prophet (PBUH) laid the foundation of Islamic 
government in the short state of Madinah Munawwara and set a high example of Islamic system of government through prophetic wisdom. He agreed with the Jews of Medina to live together according to international principles. He established the highest principles of peace and war and acted in accordance with them. These principles and teachings are such that they can cure the problems of the world even today. The basic principles of the politics and strategy adopted by the Prophet (peace be upon him) are as applicable today as they were practically successful in the time of the Prophet and in the early days of the Muslims.

In the beginning, when the Islamic government was limited to Madinah and its environs, all administrative and political matters were decided by the Prophet (sws) himself. After the conquest of Makkah, when all the Arabs became Muslims and the boundaries of the Islamic state spread, the Prophet (peace be upon him) appointed separate rulers for each region. Authorities were appointed for different parts of Makkah, Oman, Bahrain, Tayma and Yemen. The Arabian Peninsula was the most populous and extensive region and its ancient civilization was also famous. In addition to being located on a commercial highway, its commercial business was also developing. It was also important in terms of agriculture and handicrafts, so the Holy Prophet (sws) paid special attention to its administration, system of governance and appointment of officials.

\section{Women's rights:}

The woman is the adornment of the house and nature has given her the responsibility of the home. These days, Muslim women are being evicted from their homes in the name of freedom and they are being pushed into misguided behavior and obscenity. If we look at the results of this so-called freedom in the West, it is clear that because of this freedom, 
their families have been forced to live a helpless life like animals. If we look at the pre-Islamic situation, women's rights were violated and women were not given shares in property. Islam gave inheritance right to woman for the first time in human history.

The Qur'an says:

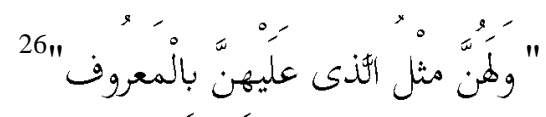

"According to the constitution, women have the same rights over men as men have over women"

Hazrat Abu Hurarah (may Allah be pleased with him) narrated that the Holy Prophet (peace and blessings of Allah be upon him) said:

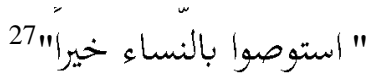

Treat women well.

The world today is proud to have given women equal rights even if the facts are not distorted. And a realistic study of history reveals the fact that the teachings and biography of the Holy Prophet (PBUH) first freed women from the shackles of oppression and gave them the rights to lead a dignified life in the society.

\section{THE BOUNDARY BETWEEN RELIGION AND THE WORLD:}

The unbalanced thinking in the minds of people today has confused the complete system of life. Many people today are still suffering from intellectual disorder. One group that ridicules Islamic teachings of ancient thought and another class that calls modern and scientific education the teaching of disbelief. There is a class which teaches to live a life away

\footnotetext{
${ }^{26} \mathrm{Al}-\mathrm{Qū} \mathrm{rān}: 2,228$

${ }^{27}$ Saḥ̄ḥ Al Bukhārī, Hadīth \# 3153
} 
from worldly affairs and another class wants to confine religious knowledge to the mosque.

The characteristic of the civilization that flourished in Madinah during the Prophet's time is that it did not suffer from extravagance and degradation. The affairs of religion and the world have been settled in such a way that neither religious engagements hinder worldly needs nor worldly requirements prevail over religion. Rather, the two aspects of life continued to walk together because the Holy Prophet (SWS) continued his spiritual devotion, while prayed day and night as well as managed his worldly campaigns. The purpose of the Prophet's (peace and blessings of Allah be upon him) seating and dismissal, morals and character, and his days and nights are the best example in front of the world, which made him a unique entity and possessor of beauty, by which man can easily reach our destination.

Islam is not just a religion, it is a complete code of life that has great civilization and cultural values, and this aspect has been comprehensively described in the Qur'an al-Hakim and Seerah.

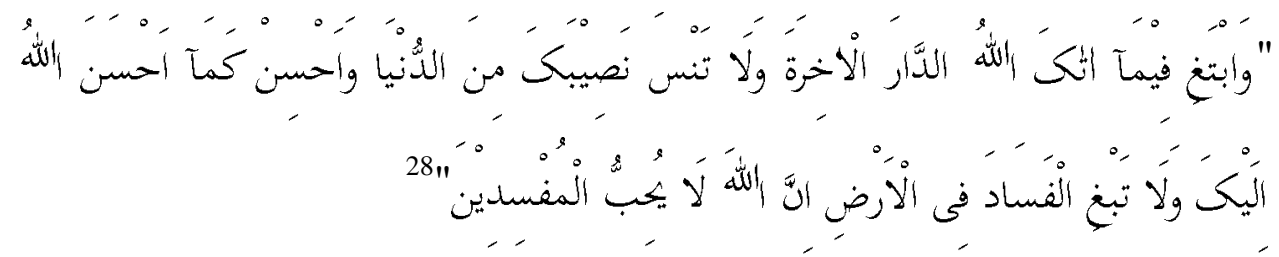

"And seek the abode of the Hereafter from what Allah has given you, and do not forget your share of the world, and do good as Allah has said to you. Do not seek (in the way of) mischief in the land (in case of oppression, concentration and exploitation), surely Allah does not like the mischief-makers"

\footnotetext{
${ }^{28}$ Al- Qūrān:28,77
} 


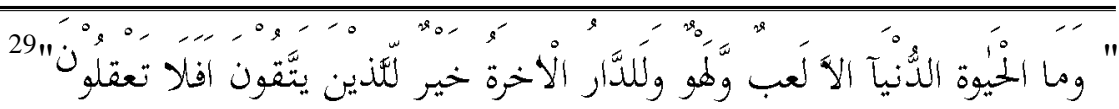

And the life of this world is nothing but sport and amusement. And surely the abode of the Hereafter is better for those who guard (against evil). Do you not then understand this reality?

\section{Military and defense weaknesses:}

Islam is a religion of peace and security and the establishment of true peace is its main goal. Islam does not allow war on anyone for no reason but commands to be ready to defend oneself at all times. Because any nation can bring real peace or end oppression only when its own defense is strong. Today, all Muslim states except Pakistan are deprived of nuclear power. The main reason for the apathy, helplessness, weakness and ineffectiveness of the Muslim states today is that the Muslim Ummah has become engrossed in internal affairs and neglected to defend itself.

However, the ruling of the Qur'an was:

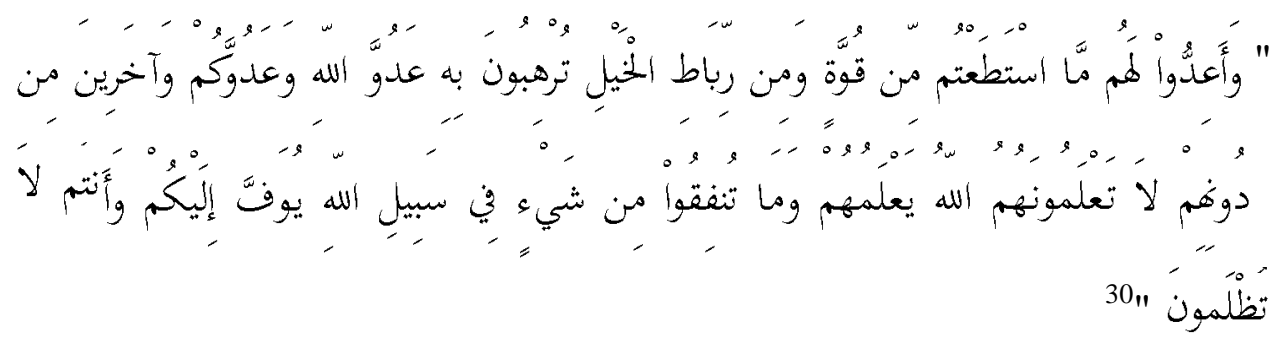

“And (O Muslims!) Provide for them as much (power and strength) as you can, and with it (the shipment of) ready horses, and make your enemies and enemies of Allah fearing with your preparation and be careful of (your duty to) your enemy and to those whom you do not know, but

\footnotetext{
${ }^{29}$ Al- Qūrān:6,32

${ }^{30}$ Al- Qūrān:8,60
} 
Allah knows them. And you will not be wronged and receive the full reward".

"As the life of the Holy Prophet (PBUH) is a beacon for us in all parts of the life it is similarly a beacon in military and defense affairs. Military measures that are necessary, the equipment and weapons that may be needed in this regard, acquisition of modern weapons, religious and military training of Mujahideen of Islam, defense and war strategy, modern armaments, full attention on defense matters and its acquisition is also an important part of his military life and biography, Thus important defense and war issues such as internal stability, military training, accurate assessment of the nature of the war, provision of material resources, weapons preparation, weapons training, combat and defense planning, battlefield mapping, consideration measures, are the matters on which he kept a close eye. He also focused on tactics, selection of combat commanders, etc and took care of them"31

\section{Moral and spiritual inferiority:}

"Today, it is incumbent upon the Muslim Ummah to work together to promote the high moral values, which it inherited from its forefathers and which it has now largely lost, and which are common to all the heavenly religions. May the attributes of trust, honesty, fidelity, justice, mutual love, compassion and respect not only be instilled in it but also become a practical example for their promotion at every individual level. Every believer should display these virtues in such a way that the hearts of

${ }^{31}$ Riẓvī, Syed Wajid, Rasūl Maydān-eJang me, (Lahore: Maktabah Madnia, 1992), p: 79 
others may not be filled with bitterness against him, but they may be drawn towards him by themselves",32

The Prophet Muhammad (SAW) described the individual and social aspects of good morals on many occasions and urged to act on them:

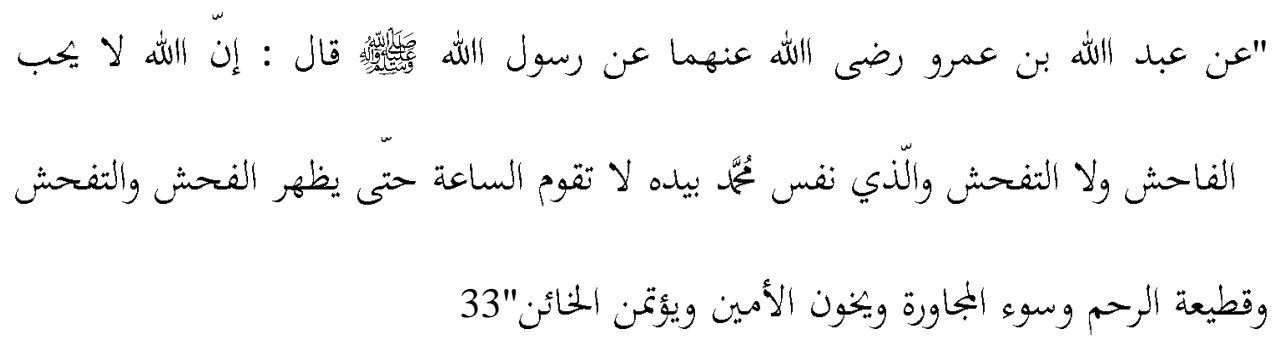

"Hazrat Abdullah bin Amr bin Al-Aas (may Allah be pleased with him) narrated from the Holy Prophet (peace and blessings of Allah be upon him) that he said: Allah Almighty dislikes immorality and slander. I swear by the One who has power over my soul! Doomsday will not come till immorality, indecency, unkindness and bad neighbours may not become common. The trustee will be called a traitor and the traitor will not be called a trustee".

\section{Sexual (physical) assault and violence:}

Incidents of sexual abuse and violence are on the rise, and the victims are especially among young boys and girls. Considering the causes of sexual incidents, one of the major reasons is delay in marriage. Islam has given a legal system of marriage and a formal system of marriage in order to regulate the sex life and protect it from moral depravity. Through which humanity has found a very suitable solution to the sexual problem.

\footnotetext{
${ }^{32}$ Saeed Akram, Prof, 'Așar-e-Hāệir or Islāmī Mu'āshry kī Tashkīl, (Tarjumān al Qur'ān, Jan 2006), p: 270

${ }^{33}$ Al Ḥākim, Al Mustadrak 'ala al Șaḥịhayn, Ḥadīth \# 253
} 
The Holy Prophet (sws) has given clear instructions in this regard through the Qur'an and Sunnah:

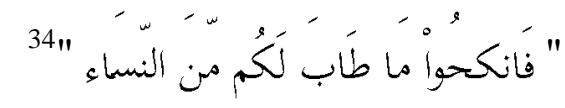

"So marry women who are adored and lawful for you"

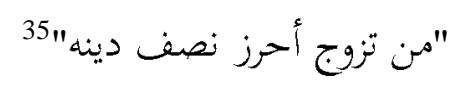

"He who got married saved half his faith".

\section{Young generation suffers from depression:}

Today, young people are suffering from various economic and social problems; Islam has given a positive attitude in the form of spiritual, mental and physical activities to eliminate anxiety in young people. So that their character can be saved from disintegration and they can be associated with love and worship of God, and a life of piety and sobriety. The Holy Prophet (PBUH) urged the youth to be molded in the framework of spiritual thought and action to save them from distractions and misguided attitudes and to give them effective instructions and teachings.

$$
\text { "أدبوا أولادكم على ثلاث خصال حب نبيكم وحب أهل بيته وقرأة القرآن"36 }
$$

"Teach your children three things: love your Prophet (peace and blessings of Allah be upon him), love Ehl-e-bait and recite the Qur'an."

Similarly, the Holy Prophet (PBUH) through his blessed Sunnah encouraged the youth to engage in healthy activities and sports besides jihad, love of God and love of the Holy Prophet (PBUH). In addition to the

\footnotetext{
${ }^{34}$ Al- Qūrān:4,3

${ }^{35}$ Al Jawzī, Al 'Ilal al Mutanahiyyah, 2: 612

${ }^{36}$ Al Hindī, Kanz al 'Ummāl, Hadīth \# 45409
} 
military and defense arts, the patronage and encouragement of sports such as archery, wrestling, swimming, running, javelin throwing and weightlifting is also proved directly from the Holy Prophet (PBUH). The Prophet (peace and blessings of Allaah be upon him) used to associate youth and children with positive and healthy physical activities.

\section{Poverty and unemployment:}

Poverty and unemployment is a problem that afflicts most Muslim countries, from our rulers to the poor people all indebt of non-Muslim countries. Sometimes we spread hands in the form of loans and sometimes in the form of aid. When the helpless people get no support, they go abroad and earn their living by staying away from their families for years. Disappointment spreads when people are suffering in different countries to earn a living and their leaders and rulers are enjoying themselves in palaces. Things get worse when the leadership is incompetent or not sincere.

Dr. Yousef al-Qaradawi writes:

The fact is that poverty is a great danger to religion and faith, especially in a place where there is an abundance of wealth. In such a situation, poverty inevitably falls prey to the suspicion that Allah (swt) is discriminating against him in the distribution of sustenance. ${ }^{37}$

\section{USE OF DRUGS:}

Islam has solved this problem forever by declaring alcohol and all other drugs as haram. The global drug prevention campaign that is being run around the world today but The Prophet of Islam started it 14 centuries

\footnotetext{
37 Yūsuf al Qaraḍāvī, Dr, Mushkilāt al Faqr wa Kayfa 'Allajahā al Islām, (Lahore: Maktabah Islāmia, 2004), p: 28
} 
ago with this proclamation. But despite this, drugs are being used extensively in Muslim countries. It is also a huge external conspiracy to mislead the new generation and put their future at stake.

In the Qur'an, Allah says:

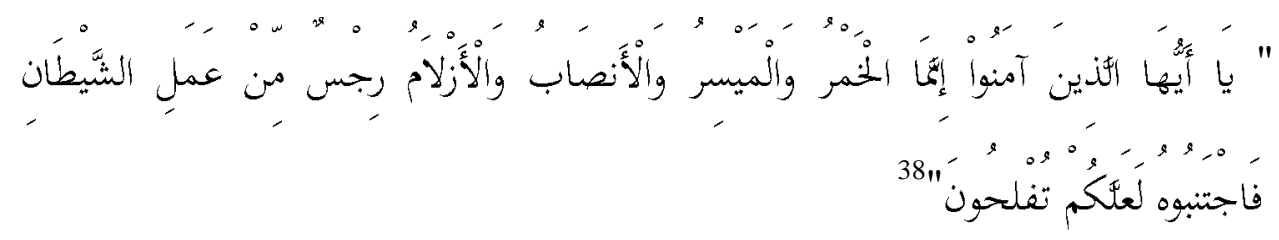

"O you who believe! Surely wine and gambling and idols set up (for worship) and divination arrows (for fortune telling) are (all) unclean evil deeds. So keep away from them, so that you may prosper".

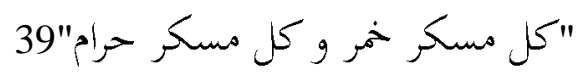

"Every intoxicant is alcohol and every intoxicant is haraam" " لعن الله الخحمر وشارها وساقيها وبائعها ومبتاعها وعاصرها ومعتصرها وحاملها والمحمولة

"Allah has cursed the wine and cursed the drunken and the drinker and the seller and the buyer and the squeezing and the squeezer and the bearer and the one for whom it was raised"

\section{CONCLUSION:}

1. In order to solve the problems and challenges that Muslim states are facing today, it is necessary for the Muslim Ummah to return to its center and make the followers of Allah and His Messenger its axis, with

\footnotetext{
${ }^{38}$ Al- Qūrān:5,90

${ }^{39}$ Sahịh Muslim, Hadīth \# 2002

${ }^{40}$ Abù Dāwūd, Al Sunan, Hadīth \# 3674
} 
perseverance in Islam. Let us follow the path of self-sacrifice and sacrifice for the glory of Islam. Let us create the ideal spirit of mutual unity and harmony, brotherhood and collectivity and universality which is the distinction of our religion and the religious and national motto of the Muslim Ummah.

2. It is the responsibility of scholars, intellectuals, thinkers and the media to address the perception of terrorism, extremism and intolerance in the Muslim world.

3. For the moral and spiritual training of human beings, it is necessary to make them aware of the basic teachings of Islam and in order to compete with the developed countries in modern times, it is necessary that modern sciences be disseminated at every level.

4. For the moral and spiritual training of human beings, it is necessary that they be made aware of the basic teachings of Islam and in order to compete with the developed countries in modern times, it is necessary that modern sciences be disseminated at every level.

5. For young people and the younger generation to think positively, it is necessary to create an educational and creative environment in accordance with modern requirements where they can use their talents in a positive way.

6. The economic class system should be abolished and the economic system should be based on equality and moderation keeping in view the Islamic principles.

7. The time has come for the Muslim Ummah to put aside its differences and recognize its real enemy and to hold the rope of unity and consensus, to come together on one platform and become a support for the oppressed Muslim Ummah. 
The Scholar Islamic Academic Research Journal

Vol. 6, No. 1 || January-June 2020 || P. 379-409

https://doi.org/10.29370/siarj/issue10aren24

8. For the solution of all internal and external, economic and social, political and social and moral and spiritual problems of life, Sira-e-Taiba should be studied and these teachings should be made a part of one's practical life and conveyed to the people.

9.Media is a great weapon of today. Muslim states should pay special attention to media through which the spread of Islamic civilization and culture and the cultural invasion of Western media can be stopped.

\section{(C)(1)(0)}

BY NC SA This work is licensed under a Creative Commons

Attribution-NonCommercial-ShareAlike 4.0 International (CC BY-NC-SA 4.0) 